\title{
The emergence and development of fair relativity as a state pay fixing criterion in New Zealand
}

\author{
Ian Powell*
}

This paper discusses the emergence and development of fair relativity as a state pay fixing criterion, culminating in the adoption by Parliament of the State Services Remuneration and Conditions of Employment Act 1969. Within the theme of the evolution of fair relativity as a state pay fixing criterion, two questions prevail. First, was this evolution through consensus or conflict, and second, was the state sector central union leadership wise and proactive or unwise and reactive in its approach to this issue. Discontent over state pay fixing procedures and criteria in the period 1962-67, particularly insofar as it contributed to the establishment of the 1968 Royal Commission is outlined, along with the CSSO boycott debate and decision. The debate between government departments and external organisations within the Royal Commission is discussed, with particular regard to the pivotal submissions of the SSC, Treasury and the Employers' Federation. The report and recommendations of the Royal Commission concerning pay fixing criteria are examined along with the subsequent disputes and negotiations between the SSCC and CSSO leading to the 1969 Act.

\section{Ironies of looking backwards}

From early 1986, when the Labour Government established a consultative committee to examine the principles and procedures of state pay fixing and associated conditions, until 1 April 1988, when the State Sector Act was enacted, there was controversy and debate over state pay fixing criteria, and fair relativity in particular. This was especially true once government intentions became clearer through the introduction of legislation in December 1987. One of the consequences of this process was the end of the fair relativity criteria through the repeal of the State Services Conditions of Employment (SSCE) Act 1977, notwithstanding S.148 of the Labour Relations Act 1987.

Twenty years earlier, specific fair relativity criteria had been investigated, debated, and finally introduced through the State Services Remuneration and Conditions of Employment (SSRCE) Act 1969, from which the subsequent 1977 Act was derived. Despite the different outcomes, the two processes were similar in the non-participation of

New Zealand Educational Institute. The views in this paper are those of the author, and not NZEI. An earlier version of this paper was submitted for the Diploma of Industrial Relations at Victoria University of Wellington. I would like to thank Pat Walsh for his comments and assistance. 
the central state sector union organisations in the reports that preceded the legislation. The Combined State Service Organisations (CSSO) simply refused to participate in the 1968 Royal Commission, while in 1986 the Combined State Unions (CSU) withdrew from the consultative committee, leaving it in the hands of the State Services Commission (SSC), along with Treasury (and to a lesser extent the Department of Labour). An important difference, on the other hand, is that whereas the SSRCE Act was the outcome of intensive and rigorous negotiations following the Report of the 1968 Royal Commission, there was no comparable negotiation following the consultative committee's report. The CSU considered that only an unprecedented campaign of industrial action would influence the Labour Government's handling of the State Sector Bill.

Fundamental ironies also appear in comparing the two pay fixing policy processes. In the $80 \mathrm{~s}$, for example, Minister of State Services Stan Rodger was instrumental in introducing and enacting legislation which would, without negotiation, repeal state pay fixing criteria. He repeatedly criticised CSU leaders for not participating in 'discussions' with government over the content of the State Sector Bill. Twenty years earlier, however, as a senior Public Service Association (PSA) leader, he had played an important role in the CSSO response to the 1968 Royal Commission - including the decision to boycott proceedings and the subsequent intensive negotiations with the State Services Coordinating Committee (SSCC) over the content of the SSRCE Act. Even more fundamental was the central employer and union organisations' change in attitude towards fair relativity as pay fixing criteria. In 1986 the SSC alleged that fair relativity had often established linkages ". . . without regard for the relevance of those relativities for the 'market' price of an occupation". The SSC concluded that relativities ". . . has tended to react inflexibly to pay changes occurring in any part of the system" (Dept. of Labour, p.29). In anger the CSU responded that while acknowledging that there were faults the relativity criteria, were sound (PSJ, 1986). Ironically, in the period 1968-69, the SSC had strongly advocated fair relativity as the prime pay fixing criteria against the opposition not only of Treasury, but also of the CSSO, which considered the Royal Commission's criteria, subsequently embodied in the SSRCE Act 1969, as rigid and inflexible. What was rigid and inflexible to the CSSO in 1968-69 was the reverse in 1986-88, while what was rigid and inflexible to the SSC in 1986-88 was the reverse in 1968-69.

In light of the above, the assessment provided by Norman King and John Gordon (Opposition Waitemata MP and Minister of Labour respectively) during the second reading debate on the SSRCE Bill may have been prophetic. In response to the former's statement that "... changing circumstances may not allow for relativity always to be the influence that it will be under the Bill... ", the latter observed that "I certainly agree with the member for Waitemata that there will be changed conditions in the future and that the criteria set in this Bill may well not be the perfect answer 10 years from now" (NZPD 1969a, p.3381).

\section{The development of fair relativity, $1945 / 46-1962$}

Labour Prime Minister Peter Fraser's decision in February 1945 to establish the Public Service Consultative Committee (with equal Public Service Commission (PSC) and PSA representation) was the first formal step in the development of fair relativity as state pay fixing criteria. Prior to the 1940 s, senior salaries were fixed by cabinet with most other state salaries set by order-in-council. Fraser's move followed his offer of 12 months earlier to establish mandatory or advisory tribunals to consider pay claims and was immediately after the call of the PSA in late 1944 to establish a bipartite PSC-PSA consultative committee to formulate new salaries. The committee's establishment was a key element in Fraser's objective of developing a post-war salary pattern (Robertson, 1974, p.115; Roth, 1987, pp.108-110; and Hunn, 1982, pp.47-48). Twenty years later the SSC noted that the establishment of this committee marked the first time that Instrumental background factors in the establishment of the bipartite committee included wildcat strikes in response to a Government Railways Tribunal decision in 1944 and the emergence of a new, assertive, left-orientated PSA leadership, the 'Korero', in the mid1940s (Walsh, 1988, p.10).

Although the committee's bipartite report proposed new salary scales, more important was its strong recommendation of fair relativity as a state pay fixing criteria. The committee observed that dissatisfaction among public service employees on salary matters had been periodic since 1920 and compounded in the early 1940s when the average salary of public service employees had increased by a "considerably lower percentage" than the average salary of "all breadwinners". It concluded that it was necessary to bring salaries of public service employees into line with the earnings of comparable workers in industry when they were below them (Public Service Consultative Committee, 1946, p.74).

Conscious of the "... disparity in salaries of public servants and those of comparable workers outside ...", especially in the first three years of World War Two (ibid., p.8) and the severe recruitment problems in the public service, where there were often few applications for positions, and sometimes none of the applicants were suitable (ibid. p.22), the committee recommended the following basis for fixing public service salaries:

In the interests of an efficient and contented Public Service and with due regard for equity as between the people and their employees, Public Service salaries should be on the basis comparable with the rates paid to people in corresponding classes of private employment (ibid., p.10).

In addition to recruiting and retaining an efficient public service, the committee was also concerned that pay fixing be equitable and fair to the employees affected. It affirmed that:

It is equitable that the employee of the State should be enabled to maintain the same standard of life and comfort as that enjoyed by comparable work in private industry in the same locality ... The principle of fair relativity to wages paid in comparable outside employment is equitable, both to the employees and to the citizens who employ them (ibid., p.24).

The committee, noting the decision of the British Government in 1910 to adopt the principle of fair relativity, recommended the following state pay fixing criteria:

(1) Salaries should be comparable with rates paid to people in corresponding classes of private employment.

(2) The functional content of the services rendered should be valuated to enable low paid state workers to maintain a fair and reasonable standard of living.

(3) Specific allowances should be paid to meet local and individual conditions, abnormalities and responsibilities (ibid., pp.24-25).

The report and in particular the principle of fair relativity became the basis for state pay fixing until further developed in the State Services Act (SSA) 1962. However, postwar problems in fixing pay rates emerged and there was an increasing tendency for private sector payments to be made above award rates. This led to "grave difficulties" in recruiting sufficient competent staff. The state sector unions agreed with the National Government's decision in 1950 to establish ruling rates surveys (SSC, 1966, Appendix 1). Surveys were held most years from 1950 until the SSRCE Act. Although imperfect 
and inadequate, these ruling rates surveys gave a more practical effect to the fair relativity principle than any other developments of the time (Robertson, 1974, p.116; for pistorical account of the ruling rates survey, refer to RC Submission No. 84).

Meanwhile, pressure was growing for a commission of inquiry into the state services. Following a call for such an inquiry by the Institute of Public Administration in 1957, Following a call for such an inqued action in the general election campaign later that year. the National Government pledged action in the general election campaign later that year. However, National's electoral defeat, coupled with lack of enthusiasm from both the new Labour Government and the state sector unions, meant that momentum was lost and did not resume until the National Party reissued its pledge in the 1960 election campaign (Royal Commission, 1962, p.3; Roth, 1987, p.157). Following its return to the Treasury benches the Holyoake Government kept its pledge by establishing, in July 1961, the Royal Commission of Inquiry into the State Services in New Zealand with Supreme Court judge Thaddeus McCarthy as chairman. The commission's warrant was very wideranging and not confined to pay fixing. The warrant required the commission to report on both the machinery for wage and salary determination and "... the principles on which wages and salaries should be based." Thus it was restricted in its examination of pay fixing because of both its extensive warrant and its direction to examine "principles" rather than criteria.

The commission's report made a strong statement on the importance of basing pay fixing on principles, given the state's unique nature as an employer. It asserted that:

... it is important that the wages and salary of State servants should be fixed according to principle.... because the State is not an ordinary employer: for example, fixing the salaries of its servants, and imposing taxes to pay for them, are potentially of political significance. If the non-political character of the State Services is to be maintained, their pay disputes should not become matters of party-political controversy. For the very reason that the State is not an ordinary employer, its pay rates must be fixed according to principles which are acceptable to successive Governments, whatever their political complexion (also, as far as possible, to the general public and to State servants themselves). State pay rates must therefore not be left to the arbitrament of political pressure (Royal Commission, 1962, p.342).

The commission accepted that the recruitment and retention of an efficient staff were the first requirements in determining state pay fixing principles. The role of the state meant that this was in the national interest and therefore an absolute principle. However, meant that this was in the national interest and therefore an absolute principle. However, on its own the principle of recruitment and retention was insufficient. It could not suggest an upper limit to remuneration levels and was also insufficiently sensitive as a test for determining a minimum rate (in that it could only identify the problem after damage had occurred to the efficiency and morale of the service). Furthermore, as a pay fixing principle it could not indicate the increase necessary where damage was evident. Thus, fair relativity was needed to indicate the pay levels necessary to recruit and retain an efficient staff, to quickly indicate areas needing adjustment and the levels of such efficient staff, to quickly indicate areas needing adjustment and the levels of such
adjustment, and to represent a standard accepted as fair by government, employing authorities, workers and the public. In furthering this advocacy the commission referred to the 1946 Consultative Committee Report and the 1955 Report of the British Roy

. ly employer, such as pricon officers and lighthouse keepers, the commission accepted that there was a case for internal horizontal relativity as a pay fixing principle. It also accepted that there was a case for proper margins of responsibility within the state service through internal vertical relativity. Nevertheless, it feared that internal relativity (horizontal or vertical) might assume primacy among pay fixing principles which could generate a chain reaction among occupational groups (ibid., pp.348-350). Consequently, in concluding that the fair relativity principle was vital in pay fixing principles, the commission decided that external relativity should be the prime consideration. Internal relativity should only apply where there was no comparable external employment, external rates were themselves based on state rates, or conditions of service other than salaries or wages were sufficiently different to prevent a fair comparison with outside employment (ibid., pp.343-352).

These conclusions led to the commission making two recommendations on pay fixing principles:

(104) Wage and salary rates in the State Services be fixed wherever possible according to the principle of fair relativity with the current remuneration of those doing broadly comparable work in outside employment....

(105) Where no proper comparison with broadly comparable work in outside employment is possible, those wage and salary rates be fixed by comparison with such other group or groups within the State Services as may be deemed appropriate (ibid. p.408).

The National Government promptly accepted these recommendations, which were incorporated into S.41(5) of the SSA, although the commission's concerns (including for example margins for responsibility) were spelt out in the Act to a greater degree than they were in Recommendations 104 and 105

Subclause (5) should also be read in the context of subclauses (2) and (4) which instruct the SSC to prescribe occupational classes according to the nature of the duties to be performed by the permanent staff and to subdivide each occupational class into grades according to its assessment of the relative levels of responsibilities and skills required to be exercised by employees in the class. In this context, subclause (5) required the SSC in prescribing salary rates or scales of salary rates to have regard to external fair relativity, to the need to maintain adequate margins for skill and responsibility, to the need to provide sufficient inducement for recruitment where external fair relativity was not possible or appropriate, to fair internal relativity, and to other matters agreed to between the SSC and the unions concerned.

\section{Discontent over pay fixing criteria, 1962-1967: establishment of another Royal Commission}

The SSA was essentially consensus legislation and did not generate controversy. There were murmerings of discontent, however, not so much over the provisions of S.41(5), but over other related factors. In particular there was a slow but increasing frustration with the ruling rates survey as a means of measuring the fair relativity principle.

The 1962 Royal Commission had been critical of the Department of Labour's ruling rates survey because, despite being narrowly based on private sector tradesmen and labourers in the engineering and building industries, it was used to establish levels of remuneration for all state employees including those in clerical and professional occupations. As an alternative, it argued for a pay research unit, attached to the Department of Statistics, to assist in external comparisons for all occupational groups (Royal Commission, 1962, p.353-56). Although it recommended accordingly (ibid., Recommendation 106, p.409), the commission acknowledged that it would take some time before such a unit could be established and therefore recommended the continuation, as an interim measure, of the survey, but on a six monthly basis and with no general 
wage order provision (ibid., Recommendations 107-108, p.409). The Holyoake Government responded by providing for the first time the legislative authority for the continuation of the survey in S.42(1) of the SSA in order to maintain fair relativity.

Treasury was one of the critics of the ruling rates survey during the period between the two Royal Commissions. As part of an inter-departmental committee ${ }^{1}$ reporting on general wage orders and other wage-increase procedures in New Zealand, it identified the application of ruling rates surveys to government employees as tending through its averaging process to generate wage spirals, inducing private sector employers to "raise their bids for labour" in areas without severe competition and resulting in private the outside rate (Interdepartmental Committee, 1966, p.6). In contrast, the SSC argued in its annual report to Parliament that the state followed the private sector, and that it was the reaction of outside employers, not the survey itself, that created an inflationary effect. Private sector employers were attempting to preserve a margin over public service rates by granting equivalent increases (SSC, 1965, p.11). Nevertheless, the SSC still bemoaned the slow progress in establishing a pay research bureau as recommended by the 1962 Royal Commission.

Defending the survey against the wage inflation accusation did not mean, however that the SSC was unconcerned about the impact of the survey on the application of the principle of fair relativity. In an internal paper on the ruling rates survey and wage fixation written in November 1966, while accepting that it was the best system to date, the SSC acknowledged that it was "rough and ready" and had serious disadvantages because:

(1) It was unable to measure private sector "privileges" such as six monthly annual bonuses, use of cars, free telephones, and special discount rates for purchases.

(2) It was unable to take into account state service advantages such as superannuation scheme, security of employment, sick leave and study provisions.

(3) Whereas the ruling rates were based on urban rates and then applied nationally, private sector regional rates were often lower.

The SSC also compiled data revealing that over a nine year period private sector tradesmen's rates had moved 3.6 percent more than clerical rates and 5.1 percent and 4.1 percent more than skilled labourers and labourers' rates respectively. This was 2.1 percent more than the overall private sector movement (Table 1). The SSC accepted, however, that there was no practical method yet to be found for surveying clerical outside employment and therefore the tradesmen's survey was still necessary (SSC, 1966). Fou months later a SSCC subcommittee, in an internal document, again criticised the ruling rates survey in the context of its being the measurement for the fair relativity principle. According to the subcommittee, this mechanism was deficient because:

(1) The application of the fair relativity principle was restricted by the unavailability of the type of information that a pay research bureau could provide.

(2) The survey was too narrowly based, confined to tradesmen and labourers, for what was now its main objective of measurement movement.

(3) There was no satisfactory agreement for reconciling increases for specific classes with the general increases provided by the ruling rates survey.

(4) Treasury was concerned about the effect of backdating when large sums of money were injected into the economy.

(5) Recent tribunal decisions, for example the Railways Tribunal, appeared to ignor the survey estimates when establishing a rate for tradesmen.

1 1966. Also comprising the Departments of Labour, Industries and Commerce, and Statistics, but not the SSC .
Table 1: Comparison of annual increases under half-yearly surveys with increase for tradesmen, labourers and clerical and related groups, April 1957-April 1966

\begin{tabular}{lccccc}
\multicolumn{7}{c}{$\begin{array}{c}\text { Annual percentage increase } \\
\text { Half-yearly survey } \\
\text { (All private sector groups) }\end{array}$} & $\begin{array}{c}\text { Skilled } \\
\text { Tradesmen } \\
\text { Labourers }\end{array}$ & Labourers & Clerical, etc. \\
\hline 1958 & 1.7 & - & - & - & - \\
1959 & 2.5 & 3.0 & 3.5 & 3.6 & 2.6 \\
1960 & 5.1 & 9.2 & 7.8 & 8.0 & 8.3 \\
1961 & 4.7 & - & - & - & - \\
1962 & 2.7 & 3.8 & 4.4 & 4.5 & 3.5 \\
1963 & 3.3 & 3.7 & 2.7 & 2.8 & 3.4 \\
1964 & 2.6 & 3.3 & 2.3 & 2.4 & 3.3 \\
1965 & 6.7 & 7.5 & 7.4 & 7.6 & 6.9 \\
1966 & 3.5 & 5.2 & 3.7 & 3.8 & 5.0 \\
\hline Total & $\overline{39.4}$ & $\overline{41.5}$ & $\overline{36.4}$ & $\overline{37.4}$ & $\overline{37.9}$
\end{tabular}

Source: SSC, Ruling Rates Survey and Wage Fixation, Appendix 5, 3 November 1966

The problem for the SSCC was that, despite these criticisms, this system could not be replaced with a fair relativity procedure for each occupational group or class. It would be impossible to administer for all of them (and if attempted would leave some groups penalised) and such a procedure would not be suitable for all branches of the state services (SSC, 1967; also Robertson, 1974, pp.121-126, for the inadequacy of the survey on halting a wage drift to non-government areas). An additional, albeit mildly expressed issue raised by the SSC was that of staff shortages in specialist areas. In its annual report to Parliament for the year ended 31 March 1966, the SSC noted that private employers were often willing to pay a higher rate than the public service because only a few employees were affected. The SSC, however, was required to consider the implications of salary increases over a much wider group of employees (SSC, 1966, p.27).

These issues aside, the more immediate catalyst for the formation of the 1968 Royal Commission was the outcome of a trades margins dispute between the Railway Tradesmen's Association (RTA) and Government, which began in December 1966 involved strike action, and culminated the following year when the Railways Tribunal ruled in favour of the RTA by granting a margins increase in addition to the 1967 ruling rates survey (Roth, 1987, pp.187-188). The decision generated government criticism and the suggestion that legislative change was necessary to prevent tribunals from restoring margins. This was promptly identified by the state sector unions, particularly the PSA, as a threat to their members' conditions of service (PSJ, 1967a; 1967b; 1967c and 1967d). That the Railways Tribunal decision was a key factor in the establishment of the second commission in February 1968 was recognised by the commission itself. In its report the commission acknowledged the impression that the controversy was the reason for its formation and the reason why several of the major unions refused to participate. It conceded that while the terms of reference went well beyond the dispute, it was possibly a catalyst for its formation (Royal Commission, 1968, p.7)

It is useful to look at the significant differences between the 1962 and 1968 Royal Commissions. First, the 1968 Royal Commission's warrant was confined to pay fixing, whereas its predecessor had a much wider brief. Second, the 1968 commission was directed to examine and report on pay fixing "criteria" rather than the more loose "principles". Related to this was the requirement to report on the relative weight that should be given to each criteria if more than one was considered appropriate. Third, the 
1968 commission, unlike its predecessor, followed an industrial dispute. It did not have the legitimacy of an election mandate. Fourth, the 1968 commission was to report no only on salaries and wage fixing but also on terms and conditions of employment. Finally, whereas in 1962 the commission coverage was of the public service, along with the smaller legislative and railways departments and the Post Office, in 1968 it covered the whole state service, including the departments of education and health, which comprised whole state service, including the departments of educati
about 20 percent of New Zealand's working population.

Given the controversy over the Railways Tribunal tradesmen's margin decision it was to be expected that the state sector unions, particularly those who were members of the CSSO, would be suspicious of the motives behind the forming of the 1968 Royal Commission (for example, PSJ, 1968b). Such was the level of this suspicion that the CSSO Central Comm from the PSA, Post-Primary Teachers Association (PPTA), New Zealand Educational Institute (NZEI), Railway Officers Institute (ROI), Amalgamated Society of Railway Servants in New Zealand (ASRS) and Post Office Association (POA), adopted two resolutions determining not to participate in the proceedings of the Royal Commission (PSA, 1968a). ${ }^{2}$ A statement released by its chairman Barry Tucker (also PSA president) outlined its reasons for non-participation. The CSSO argued that the Government was obliged to advise it what changes it sought if it wished to alter the conditions of employment of state employees. The establishment of the commission was "irresponsible and an unnecessary waste of public money" as well as denying state employees the right to conciliation with their employer. The commission arose out of the Government's wish to negate the tradesmen's margin authorised by the Railways Tribunal in 1967 and therefore the CSSO was justified in doubting Government's rea motives. The CSSO believed it would be "...illogical and inconsistent for it to make submissions to the proposed Royal Commission. To do otherwise would involve an acquiescence on the part of the organisations [affiliated unions] in an abrogation of their basic rights" (Evening Post, 1968a; also PSA, 1968b; 1968c). This decision led to critical newspaper editorials arguing with considerable validity that the CSSO was losing an opportunity for important input into state pay fixing policy-making (Otago Daily Times 1968; and Christchurch Press, 1968). Both the CSSO and the PSA came under bitter attack from the Masterton based Government Employees Association (GEA), a smal group of disaffected PSA members, whose interim president B.A. Mygind (also PSA Wairarapa Branch chairman), saw nothing sinister in the Government's motives (Truth,

CSSO Central Committee resolutions on involvement in the 1968 Royal Commission, 14 February 1968

1 That the Government be informed that the Combined State Service Organisations That the Government be informed that the Combined State Service Organisations
are extremely disappointed at the Government's unwillingness to conciliate upon the wage fixing criteria and procedures in the State Services before takin any decision to refer these matters to a Commission of Inquiry; the Combined Organisation reiterate that Government has, over a long period, rejected request (made at interviews and specifically in letters of 14th December, 1967, and 1st February, 1968) or a clear indication of the Government's own views on the matters proposed to be referred to a Royal Commission, and has thereby refused to the organisations the conciliation to which they are entitled in this field of employer/employee relations.

2 That Government be informed that the Combined Organisation will not be making submission to any Commission of Inquiry, but that Government be again advised of the willingness of the Combined Organisation to conciliate with Government when the Government is prepared to do so.

Note: The first resolution was unanimous although the NZEI and PPTA abstained from the second resolution.
1968). More pertinent, however, was a telling comment from commission chairman Sir Thaddeus McCarthy, who said that while the CSSO must "carry the responsibility" for its decision not to participate, the commission nevertheless would "...regret very much if we are to be deprived of the very great assistance which we had expected to receive from submissions from such bodies" (Evening Post, 1968b). This statement, however, was subsequently partially contradicted, when the commission reported that the nonparticipation decision did not affect it, partly because of the range and volume of submissions including those from unions such as the PPTA and NZEI (Royal Commission. 1968, p.6).

Notwithstanding the boycott decision, two of the six CSSO affiliates, PPTA and NZEI, resolved to participate although it was not, as the PSA official history suggests, a breaking of the ranks (Roth, 1987, p.192). Prior to the CSSO boycott decision on 14 February, the NZEI's Dominion Executive had already determined a policy basis for making representations to the anticipated commission including pressing for a wide range of pay fixing criteria to be held by a special teachers tribunal (NZEI, 1968a), after receiving a report from Salaries Research Officer Jim Delahunty who recommended that submissions be made in consultation with the CSSO and, with regard to a separate teachers tribunal, the PPTA (NZEI, 1967/293). At this stage the debate within the CSSO had not occurred. Delahunty also reported that whereas the Government might prefer to see more limited criteria, the CSSO considered that any restriction on the present freedom of action on a tribunal should be opposed.

The CSSO met on 31 January 1968 to discuss the boycott, which was strongly advocated by the PSA and POA. As no notice of this proposal had been given to the other affiliates, it was agreed to defer the matter to 14 February. The following day Delahunty wrote a perceptive report for the NZEI Executive outlining the reasons for and against boycotting the commission as well as identifying specific considerations for the NZEI (NZEI, 1968/35). According to Delahunty the PSA and POA, supported by the ROI, argued for a boycott on the basis of the following considerations:

(1) The denial of the right to conciliation that the establishment of the commission had created.

(2) Government was using the commission to "white-wash its efforts to reduce conditions" and attack the ruling rates survey.

(3) The commission would simply give Government, in the form of recommendations, what it wanted, as allegedly had the 1962 Royal Commission.

(4) If the unions participated and then later were faced with adverse recommendations from the commission, then Government would not consult on proposed legislative changes because the union's views had already been heard and considered.

(5) Differences between the unions, especially in the tradesmen's margins issue, may seriously divide them and make it easier for the commission to appear to act as an arbiter while bringing down a report recommending what Government wanted.

(6) Abstention would weaken the credibility of the commission while retaining the CSSO's bargaining power in respect of any Government proposals arising out of the commission's report.

(7) Any union's specific proposals for pay fixing changes could be put forward for later negotiation with Government as it was now more important to defend the ruling rates survey.

Delahunty then summarised the reasons for participation, the first three advocated by the general secretaries of the ASRS and PPTA (Peter Boag):

(1) Not every Royal Commission (for example the Royal Commission on Workers' Compensation) acted as a Government "rubber stamp".

(2) Abstention of the CSSO would not prevent the commission from making recommendations nor the Government from enacting them. 
(3) Abstention would mean allowing the issue to go by default insofar as the commission was concerned and would not impress union members.

(4) The PPTA had a specific concern it may wish to advocate concerning the separation of pay fixing procedures for teachers from those of other state employees.

(5) The CSSO did not represent all state unions or service organisations such as those representing registered nurses and education board employees. These could still be expected to make submissions regardless of the CSSO position.

He then raised four specific considerations, weighted very much in favour of participation, for the NZEI to consider. These were:

(1) The specific issue of Government attack was the tradesmen's margin decision, rather than the ruling rates survey, which did not directly affect the NZEI.

(2) The NZEI might not get another opportunity to press the case for a separate teachers tribunal for some time.

(3) Other teacher unions such as the Teachers College Association (TCA) who were not members of the CSSO may make submissions on pay fixing anyway and if boycotted the only teacher union views the commission would hear would be from non-CSSO unions.

(4) NZEI members would expect the NZEI to participate in order to defend the ruling rates survey and advocate a separate teachers' tribunal.

Subsequently, Delahunty reported to his Executive that at the CSSO meeting on 14 February the ASRS supported abstention, leaving only the NZEI and PPTA supporting participation while neither the RTA or Engine Drivers, Firemen and Cleaners Association (EDFCA) attended. Both teacher unions argued that they had longstanding policies which sought a different method of fixing teachers' salaries. The other CSSO members "sympathised" with their views and many believed that if the NZEI and PPTA were to "...confine themselves to advisory of special provisions for teachers there might not be "...confine themselves to advisory of special provisions for teachers there might not be this action could still involve the interests of the other CSSO members and, in particular, the ruling rates survey. Furthermore, there was little likelihood of Government setting up a new teachers' tribunal when one of its aims was to reduce the number of tribunals. Both unions agreed to report back the two CSSO resolutions and the discussion to their executives and if they confirmed their decision to participate then the CSSO would be fully consulted to avoid any "cutting across" the vital interests of the other members. They both abstained in the second of the resolutions establishing the boycott position (NZEI, 1968/43)

Delahunty advised his executive of the possibility that there was no real benefit to the NZEI in making an individual submission, especially as the prospects of a teachers tribunal were remote given Government intentions. Furthermore, a problem had arisen with the PPTA no longer supporting a separate tribunal; conflicting submissions from them would undermine the value of making independent submissions. Nevertheless, the NZEI's standing (management) committee confirmed the participation decision (NZEI, 1968b), although they also requested a further report by Delahunty on the NZEI's policy on pay fixing material (NZEI, 1968/52). Thus the claim by parliamentary press reporter Neale McMillan in a syndicated article that the CSSO and PSA were surprised by the decision of the NZEI and PPTA to make submissions was wrong (Bay of Plenty Times, 1968). In writing to a broadcasting employee in Masterton, PSA General Secretary Des Long stated that the CSSO was aware that the two unions would make separate submissions, but it had been agreed that they would only comment on individual policies and not on general issues affecting the CSSO as a whole (PSA, 1968d).
The d criteria

Given the CSSO's preference for broad based criteria, its decision to boycott the proceedings of the 1968 Royal Commission was unwise. It absented itself from critical debate over pay fixing criteria and, in particular, the significance and weighting of fair relativity and its relationship with recruitment and retention. It was left to government bodies, especially the SSC and Treasury, and private sector organisations such as the Employers' Federation, to influence the commis bodies provided extensive background papers on issues such as bodies provided extensive background papers on issues such as ruling rates surveys, the historical development of state pay fixing, tribunals, the pay research unit, and oversea systems, they also were actively advocating and debating proposals.

Three of the 144 submissions to the commission became the pivotal points of the debate over pay fixing criteria. These were written by the SSC , Treasury and the Employers' Federation (RC Submission Nos. 32, 42 and 93 respectively). The SSC, its submission, identified the following difficulties with the existing pay fixing criteria for the wider state services including the public service:

(1) It did not take in account overseas salaries for comparable occupations.
(2) There was a difficult relationship between the public service and local authoritie with comparable occupations. Some local authorities were deliberately paying higher rates than the public service in order to recruit staff.

(3) There was a problem in making comparisons with self-employed occupations such as lawyers.

(4) There was a conflict between the fair relativity and margins for skill and responsibility criteria with regard to their legislative authority in S.41(5) of the SSA and S11(1)(c) of the Government Service Tribunal Act 1965. The Tribunal had resolved that claims lodged under the latter legislation did not bind it only to S.41(5).

(5) The criteria was not weighted (RC Submission No. 32, pp.9-23).

In formulating its recommended criteria (ibid., pp.23-35), the SSC specifically excluded regional rates, productivity (because of problems of measurement), and social and economic policy (because of the danger of government manipulation). Despite raising them as existing difficulties, the SSC also rejected the use of overseas salaries and selfemployed remuneration as criteria. Instead it recommended criteria based on the following.

(1) The primary criterion should be fair external relativity. While the SSC was not opposed to other criteria they should be subordinate. External relativity should be outside the whole state services, not just a branch of it such as the public service, and should not include the self-employed or outside rates based on state rates.

(2) Fair internal relativity was acceptable as a subordinate criterion where there was no valid external relativity. However, this should be confined to horizontal, not vertical, internal relativity.

(3) Margins for skill and responsibility were acceptable providing they were subordinate to external relativity.

(4) Recruitment and retention was a valid criterion but under firm constraints. It should be subordinate to external relativity and only applied to occupational groups, such as prison officers, where no external comparison existed. The SSC was concerned that recruitment and retention criteria could cause the state to bid against other employers and lead to a spiralling effect in circumstances where there was a labour shortage.

This submission was publicly criticised by the PSA, who opposed fair relativity as the main criteria, advocating instead that margins for skills and responsibility and recruitment and retention should have comparable status (PSJ, 1968c). The SSC was generally 
supported, however, by the Department of Health (RC Submission No.61). While the suppital Board Hospitals Act 1959 required hospital advisory Employees (Conditions of Employm committees, who had a recommendatory role for salary levels, to have regard to promoting efficiency, to monitor rates in other branches of the hospital service and in other services, and to heed Arbitration Court pronouncements. At the same time, the department believed that some consideration should be given to overseas salaries. The SSC had identified this as a difficulty, but the Department wanted a stronger statement because of the relevance to the health field, especially for attracting back to New Zealand doctors who had undertaken the health postgraduat in using an openwith a specific reference with the critcia, the Depar-employed such as ended recruitment and retention criterion, comparisons with the self-employed such as doctors should not be ignored (ibid., p.4). The Department's concerns were supported by the Hospital Boards' Association and the Hospital Officers' Association (RC Submissions Nos. 83 and 101 respectively).

The Department of Education also had specific concerns although these were not consistent with the position of the SSC. Criteria for determining teachers' salaries were inconsist derived from S.164A(1) of the Education service (RC comparability, recruitment, and intenal comparability Submission No.17). The difficulty facing the prescription of teachers salaries was that fair relativity was not relevant to teachers as there was no comparable external or public service group. Private school teacher salaries were themselves based on state rates, thereby preventing any comparative worth (RC Submission No.57, p.1 and No.111, pp.67). Although school inspectors and other professional groups were comparable and their 7). Although school insector the raching profession, their personnel were recruited from the highr and also closely related to teachers salaries and again the Submission No.57, p.2). Neither could university teacl group, as they had a research as well as a teaching function and the universities had to compete on the world market for staff (ibid., pp.3, 6-7). While not as forthcoming as the SSC and the Department of Health in preparing alternatives, the Department of Education took the same view as the SSC in opposing the extension of the criteria to cover the took the sation the retention of the margins for skill and responsibility criterion (ibid., p.6 and RC Submission No.111, margins

p.6-7)

The Railways Department had a similar position to that of the SSC. Like the SSC, it believed that there was a conflict in the criteria between fair relativity and the need to maintain adequate margins for skill and responsibility. Railways believed this conflict maintain adequate margins fotween it and two unions, the ASRS and RTA, following a arose out of a 1962 . 1949 which created the recommendations 1962 a 1962 rinciple of relativity, as of the 1962 commisson. This led the marins criteria (RC Submission No 56, pp 2measured by ruling rates surveys, and the margins criteria (RC Submission No.56, pp.24). In order to overcome this problem and to meet the needs of the department, Railways recommended the following criteria:

(1) Despite the problems with the ruling rates survey, external fair relativity should be the primary consideration.

(2) Where there was no comparable external relativity (for example, shunters and guards) internal horizontal relativity was necessary.

(3) Recruitment and retention was a valid criterion when there was proof of special Recruitment and retention was a valid criterion when there was proof of special
skills, responsibilities and circumstances in a particular occupational group. However, Railways were concerned that the criterion could be used to attract recruits at the expense of other occupations (ibid., pp.4-12).
The SSC also received strong support from the Government Statistician, who endorsed fair relativity as the primary criterion. While there could be other criteria, the Government Statistician suggested that these should be subordinate and not too many. He did not identify any other criteria (RC Submission No.103, p.1). The Government Statistician believed that, if directly applied, fair relativity was incompatible with the independent fixing of margins between occupations in the state services. Furthermore, its strict application throughout the state services was impractical, except over a limited range, because it was virtually impossible to obtain identical mixtures of occupations, training working conditions and other factors for state service and external occupations. Therefore, it must be applied in a spirit of compromise, accepting that it could never be perfect, even for identical groups, because of the problem of providing regular accurate surveys (ibid., pp.2-5). The Statistician went on to identify two types of surveys neccessary to adequately apply this principle. The first was a broad-based percentage adjustment based on a wide range of surveys outside the state services, while the second was a specific occupational survey covering a single occupation or a smaller group of occupation outside the state services and carefully matched with a similar occupation or small group of occupations inside the state services (ibid., p.5).

The only two major governmental bodies other than Treasury not to go in the same direction as the SSC were the Post Office and the Police. The former was almost lethargic in its approach, arguing that pay fixing should continue its present "evolutionary path" and that change might not be necessary (RC Submissions No.5, p.10 and No.6, p.14). Notwithstanding the 1962 commission, no criteria had been introduced for Post Office employees and it was content with the status quo. Although there was a noticeable retention loss, there was no real recruitment problem. Furthermore, the Post Office believed that turnover was caused by factors other than salary levels and cited as supporting argument the fact that women did not stop leaving the Post Office after the of equal pay legislation for the state services in 1960 (RC Submissior No.39).

The concerns of the Commissioner of Police were more to do with the unique nature of the police service than differences with the SSC. Pay fixing criteria for the police were established in a 1965 amendment to the Police Act 1958, enabling S.71 to provide in pay fixing for special conditions applicable to police, margins for skill and responsibility, recruitment, external comparison and other matters. As these criteria had not been tested there had not been a dispute over the weighting of the criteria. However, as there was no external comparable group, the Commissioner was anxious to retain the special conditions criterion (RC Submission No.75, pp.7-8).

A number of smaller professional groups, other than unions or service organisations, who had members employed in the state services made a specific push for reference to overseas salaries. The Veterinary Association wanted the criteria to include reference to the remuneration of persons doing comparable work overseas, as did the Association of Scientists (RC Submissions No. 48 and 86 respectively), while the Hospital Physicists Association sought to equate senior administrators and public servants with corresponding Australian salaries (RC Submission No. 116). In a separate submission from that of the Department of Scientific and Industrial Research, the Director of its Fruit Division recommended the salaries of scientists in other "English-speaking countries" as a criterion (RC Submission No. 89), while the University Institutions recommended the ability to recruit and retain staff against their main overseas competitors as an appropriate criterion (RC Submission No.104, pp.8-9)

The Medical Association also raised the concern expressed by the Department of Health about overseas salaries. According to the Association, competition from higher British salary scales meant that it was difficult to induce New Zealand graduates overseas to return. An investigation of the higher salaries available to medical specialists in Britain 
was recommended with the further suggestion of a possible international relativity criterion (RC Submission No. 52). However, a further submission by the Association launched into a somewhat vitriolic tirade against the "evils of the salary system", especially for doctors. Criteria was not always needed as pay fixing could be better determined by considering the job characteristics of the positions concerned. With more than a hint of professional arrogance the Association maintained that the medical service should not be seen as part of the state services (RC Submission No. 79). The Association was subsequently strongly criticised in a reply by the Department of Health, which accused private doctors of abusing the social security scheme (RC Submission No.109, pp.7-9).

Treasury, in marked contrast to the SSC, advocated recruitment and retention as the key criterion (RC Submission No. 42, pp.13-20). For Treasury "... the question of remuneration of labour should be seen fundamentally as a problem of supply and demand in the labour market" (ibid., p.9). However, fair relativity (both external and internal) dominated existing pay fixing criteria (ibid., p.22) and was vulnerable to four strong criticisms. These were:

(1) Fair relativity was difficult to define because of the limitations of the ruling rates survey which did not include bonuses.

(2) Defining comparable external occupations was a problem because many state employees had no external counterparts. This led to pressure for the use of internal relativity which, in turn, had an inflationary effect and generated the most criticisms of fair relativity.

(3) Determining which employers should be taken into account in deciding the external ruling rates was a problem. Rather there was often a spread of outside rates because, for example, the job content of a specified occupation could vary considerably, fringe benefits could compensate for lower wages, an employer's cost structure and whether the cost of specific labour was a small or large part of the total operating costs had an effect, and labour costs were lowered by the geographic immobility of labour.

(4) Fair relativity was inflexible in that it made the state a follower rather than leader of salaries and wages. (ibid., pp.27-32).

Treasury then recommended that the primary criterion should be the "price for labour"; that is, the quantity and quality of labour necessary to maintain and increase the efficiency and economy of the state services (recruitment and retention). External fair relativity was to be relegated to one of the factors that would be taken into account in setting the "price for labour" while there would be no place for internal relativity as Treasury was unconcerned about whether, for example, a doctor, scientist or engineer could be paid more than a permanent departmental head. Treasury's recommended factors to be taken into account for settling the "price of labour" were:

(1) The price for external comparable occupations, careers or qualifications of labour.

(2) The desirability of increasing the total supply of a particular type of labour available to the economy as a whole.

(3) The degree to which the supply of a particular type of labour could or should be redistributed between public and private sectors by variation in the labour price.

(4) External fair relativity only where necessary with a preference against comparisons of entirely different types of occupations.

(5) Any other mutually agreed matters (ibid., pp.32-39).

The Employers' Federation maintained that S.41(5) failed to translate into legislative form the precise recommendations of the 1962 commission (RC Submission No. 93, pp.8-29). Instead of fair relativity, the Federation used the term "fair comparison", which had previously been used by the Priestley Commission. Specifically, margins for skill and responsibility were not necessary because they were already catered for by relativities or "fair comparison", and the provision for margins in S.41(5) was an imposed artificia criterion. Also, external fair relativity should be extended to take into account regiona variations. The Federation recommended "fair comparison" with outside employment as the primary criterion and internal relativity as a subordinant criterion. It criticised both Treasury and the 1962 commission for their advocacy and acceptance of recruitment and retention. It stated that the state must compete fairly with the private sector and must not have an unfair advantage in recruitment. Furthermore, "fair comparison" was sufficient to meet recruitment and retention concerns. Under cross-examination during the forma hearings of the commission, SSC chairman A.G. Rodda acknowledged that "fair comparison" was a generic term used by the Priestley Commission and accepted by the SSC. The SSC only used the terms external and internal fair relativity to distinguis between them. During this discussion the Federation's representative broadly agreed with the SSC (RC Verbatim Proceedings, pp.87-89).

Acting in conjunction with and in support of the Federation, the Associated Chambers of Commerce agreed with the concept of "fair comparison". The Chambers' main conclusion was that, in the context of "fair comparison", the effective remuneration of public service employees, having regard to the value of fringe benefits enjoyed, was greater than their counterparts in the private sector to such an extent that an appropriate allowance should be made for this advantage when fixing salary and wage scales (RC Submission No.106, p.1). The Chambers had conducted their own survey on fringe benefits using medium and small-sized employers who were the "average good employer". These advantageous public service fringe benefits included superannuation (the major benefit), security of employment, sick leave, annual leave, study leave, special leave boarding allowances, equal pay, location allowances, housing assistance and PSIS discounts.

The survey came under close scrutiny when the Chambers General Secretary Arthur Heany appeared for questioning during the formal hearings. Rodda described it as a "not particularly sophisticated" exercise, contesting the exclusion of banks and insurance companies from the surveyed group, noting that employers' superannuation payments were tax deductible, and questioning whether the 297 responses were from "good firms". Furthermore, he criticised the accuracy of the survey's results, because the 297 responses were derived from a survey of an unknown number of businesses, making it rather a "pot shot" selection. The final rub came when Rodda concluded that "I didn't want to let the opportunity go by of trying, in a modest way, to show that frankly I don't think this survey is worth very much." He then assured Heany that this was not meant to be an attack, although McCarthy commented that "I wouldn't have blamed you [Rodda] if it was." Under further cross-examination from Commissioner Turnbull, Heavy admitted tha he did not know how to measure intangible benefits and also did not know how many of the firms surveyed not paying a location allowance would have employees stationed in remote areas (RC Verbatim Proceedings, pp.991-1003).

Notwithstanding the CSSO boycott some unions, mainly non-affiliates, did participate in the commission, but because of the CSSO's absence they lacked an overall thrust and direction that could have responded to the three pivotal submissions. In a combined submission the Police Association and Police Officers Guild argued that fair relativity was meaningless for the police and the main criterion should be the special conditions of the police followed, in order, by margins for skills and responsibility and recruitment and retention. Furthermore, partly to facilitate this, the police service should be separated from the state services (RC Submission 82, pp.9-10, 16-22 and 26).

The remaining participatory unions represented teachers. The TCA, who were not in the CSSO, recommended that the criteria be recruitment and retention, external fai relativity, internal fair relativity (but subordinate to external relativity), and the career structure. The TCA also wanted fair relativity as applied to teachers' college teachers 
weighted towards university, technical institute and Department of Education senior officials' salary scales (RC Submission No.110, pp.4-5).

Technical institutes had not been considered by the 1962 commission as the first institute was not established until 1961. The Association of Teachers in Technical Institutes (ATTI), also not in the CSSO, advocated that the best quality people must be recruited from the private sector, especially industry, commerce and the professions. argued for a strong recruitment and retention emphasis, rather than fair relativity, which should take into account "effective remuneration" in outside employment. This meant no just salaries received but also car and telephone allowances, cheap rents, special discounts, and preferentiat housing loans. The recommended criteria were remuncration sufficiently high level to recruit "better than average" experienced and well qualified staff from outside the education and state service, retention of sufficient staff to ensure the effective and efficient functioning of the technical institute service, and the maintenance of adequate margins for academic and administrative skills (RC Submission No. 102, pp.68).

As well as arguing that the education service should be outside the state services, the PPTA recommended that the criteria for teachers be (like the ATTI) a greater weighting towards recruitment and retention, relativity with external qualifications, and margins for skill and responsibility. It also recommended that less prominence be given to internal relativity (RC Submission No. 94, pp.15-17 and 24-27). The NZEI focussed more on the need for special pay fixing procedures for teachers separate from the state service, albeit in a somewhat professionally elitist manner. It did argue against common criteria for teachers. Because teaching was a separate profession with no direct relationship to other professions, it argued, external fair relativity could not be applied. Occupation classification and many interservice issues did not apply either, and salary scales and conditions of payment for teachers were different in most respects from employees in othe services (RC Submission No. 63, pp.15-16).

The SSC, meanwhile, used the opportunity to submit a final response commenting on some of the earlier submissions. It was strongly critical of Treasury's "price for labour" approach. In the SSC's assessment this gave an insufficient recognition to a basic feature private sector to the state of the labour market and to changes in state sector pay rates. Treasury's focus on state sector recruitment and retention alone or predominantly could lead to pay rates ahead of those on the private sector and therefore through catch-up an flow-on moves it would generate inflationary effects. The SSC could not support the ...setting of wages and conditions of employment which would eliminate staffing difficulties in all economic circumstances..." (RC, SSC final submission (no number), pp.1-2).

The SSC also argued against the use of broad criteria such as "equity, good conscience and the substantial merits of the case" as operated in Australia. Rather, a statutory reference to fair relativity was needed. In fact, fair relativity (external or, if not applicable internal) should be the only criteria to be considered by a tribunal whose function would hen be limited to an appellate authority. Other criteria, such as recruitment and retention, to an the negotiations process between employing authorities and unions (ibid., pp.4-5).

In response to the Employers' Federation suggestion that state pay rates should be adjusted to take account of regional variations, the SSC accepted the principle that paying for regional differences in external rates was consistent with the principle of fair relativity. But this presented "overwhelming practical difficulties" for career services such as those in the state services. The Federation had proposed two methods of handling regional variations. One was to base the national scale on the lowest rate in New Zealand and then adjust by way of allowances for all other areas below and above the average. The SSC countered that there were practical administrative difficulties in establishing area rates. The national career structure would be disadvantaged, staff immobility would be inherent, and overall state service efficiency would be reduced (ibid., pp.6-7).

\section{The 1968 Royal Commission Report}

In its 184 page report containing 62 recommendations, the Royal Commission identified as a major cause of the difficulties in the period leading up to its formation the failure of the SSA to weight the criteria, with particular regard to external relativity, margins for skill and responsibility, and recruitment and retention. Although the 1962 commission had recommended a weighting of principles (Royal Commission, 1962 commission had recommended a weighting of principles (Royal Commission, 1962, This failure led to conflicting criteria and consequent disputes, particularly over the relationship between the fair relativity and margins criteria (Royal Commission,1968, pp.7-8 and 71). Another underlying tension was the relation for specific occuptiona groups and "wage adjus for specific occupational groups and "wage adjustment" for general pay rate movements. S.41(5) provided for the former and S.42 for the latter, which was based on fair relativity. The conflict was caused by the fact that whereas the "wage fixing" criteria could, through the margins for skill and responsibility criteria, force rates above external rates, the "wage adjustment" criteria could force them down because of the confinement to fair relativity and its reliance on the crude ruling rates survey (ibid., pp.70-73).

Before discussing specific criteria the commission recorded an important underpinning principle. It recognised that labour costs had an allocative function; encouraging potential recruits towards occupations in which labour was relatively scarce and away from those which were relatively over supplied. If pay rates were the same then there would be no allocative function. There needed to be a facility to alter existing margins between state service occupations when corresponding margins in outside employment changed (ibid. p.75). This function appears to have steered the commission towards its recommented weighting of criteria.

The commission identified three problems in its discussion of external comparability. Firstly, job content was rarely identified, even with comparable occupations, because of, for example, differing expectations of quality. Secondly, there were differences such as promotion prospects, fringe benefits and the prestige of employees which meant that external comparability could only approximate net advantages. Thirdly, external pay rates were not uniform because of, for example, regional and above award variations. Thus, external comparability provided a "rule of thumb" rather than a precise measurement (ibid., pp.79-82). This approach had earlier been advocated by the Government Statistician.

The commission also addressed specific issues raised in the pivotal submissions. While acknowledging the concern of the Employers' Federation that uniform state rates could force external wages up in low wage areas (for example, unfair competition for tradesmen in districts like Wanganui), it agreed with the opposing view of the SSC (and Railways). Thus, where external rates varied considerably, location allowances were recommended as a means to address this problem (ibid. pp.82-84). The commissio concurred with both Treasury and the SSC, which, in an unusual agreement, rejected the use of criteria as a means of achieving economic policy (ibid., pp.77-78). It also agreed with the SSC in disregarding the self-employed from external comparability (considering recruitment and retention as a more appropriate criteria, particularly with the impracticality of equating incomes) and also with confining external comparability to within New Zealand, as overseas living conditions, taxation rates, social security bencits a services were likely to be too different for proper comparison (ibid., p.82). However, subclauses (5)(c) and (d) did provide a restricted capacity for such comparisons. 
The commission accepted the Treasury argument, at least insofar as "wage fixing" adjustments were concerned, that external comparability should be based on certain type of employers rather than all outside groups. Thus the comparison should be with an employed by the Government Printer were only located in Wellington and therefore should be compared only with Wellington external printers (ibid., pp.84-86).

The commission adopted the unusual step of formulating the actual legislative wording of its recommended criteria (ibid., pp.97-100 and pp.175-178, Recommendation 19). It saw no need to have reference to other factors agreed between the parties, as existed in the SSA, and rejected the SSC recommendation that employing authorities should have regard to a wider range of criteria than the tribunals. Furthermore, it rejected the inclusion as an additional criterion of productivity (because of practical measurement difficulties), although it could be incorporated into fair relativity in that an essential element of productivity agreements was that if a position's job contact changed then a new relationship with another position could emerge which would be covered by relativity criteria (ibid., pp.93-95). Manpower policy (as advocated by Treasury) was also rejected, because it was premature, it was difficult for tribunals to define priorities, and it could override government policy. Rather, manpower policy was a government responsibility, investigate it further as a possible pay fixing criterion (ibid., pp.91-93).

Within the framework of establishing pay scales to enable the state services (not just the public service as was the case in the SSA) "to recruit and retain an efficient staff", and being "fair to the tax-paying public and to employees in the State Services", the commission recommended a raft of weighted fair relativity criteria, along with recruitment and retention, in order to set a "market price" for pay. The term "market price" was to generate suspicion and concern within the CSSO especially from the NZEI. While (and the supporting (and the supporting departments), Employers' Federation or Treasury were successful in ensuring that either external relativity or recruitment and retention would predominate over the other; rather primacy would depend on the circumstances.

In developing and weighting fair relativity (ibid., pp.86-88), the commission accepted that no matter how thoroughly external comparability was applied, it was unlikely to provide for any occupational group sufficient points of comparison to enable determination of every position in the pay scale. It could only provide a framework, or series of benchmarks, within which the remaining positions in that group could be related. Consequently, a further criterion, vertical relativity, was necessary. This had been recognised in the SSA as margins for skill and responsibility. Furthermore, a marke price could not be set for those occupations where there was no external comparable groups, such as lighthouse keepers, nurses, prison officers and teachers. For these occupations the best that could be done was to maintain relativity with other state service groups for which a market price could be set and in which the work, however dissim

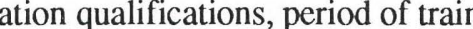
had conventionally been regarded as being of similar status. This comparison, however, was not confined to within the state services. Comparisons could be made externally by 'averaging' a number of outside groups. This criterion was named horizontal relativity.

These three relativity criteria (external, vertical and horizontal) only provided an approximation of the market price with the last being the most indirect. The commission recommended that they be weighted in order to provide a test that produced the closest approximation to the market price. The recommended weighting, in order, was:

(1) External comparability.

(2) Vertical relativity where external relativity was used for the compared internal group.
(3) Horizontal relativity, in the first instance, where the comparison was external.

The commission also addressed the sensitive relationship between fair relativity and recruitment and retention criteria. (ibid., pp.88-91). As relativity could only give approximations of the market price, employing authorities should be able to check their accuracy by closely watching recruitment and retention rates in the various occupations and changing pay rates based on relativities when "abnormal ease" or "difficulty" in recruitment and retention suggested that the rates were out of touch with market realities Only in either of these situations could recruitment and retention be an overriding consideration.

The policy of recruitment and retention, although necessary could not replace fair relativity because it was unable to indicate the amount by which pay rates should be increased if the state services were failing to recruit and retain enough efficient staff in a given occupation. It was not a sufficiently sensitive test and could only identify a problem after the damage to efficiency and morale had occurred. On the other hand, relativity tests could also be inaccurate because of their quickness. Both Royal Commissions had agreed that the external comparability criterion should be qualified so as to make it clear that the need to recruit and retain an efficient staff could, in specified circumstances, be an overriding consideration. Therefore external comparability was not appropriate as the sole criterion.

\section{Negotiating pay fixing criteria for the 1969 Act}

Following the release of the Royal Commission's Report in August 1968, the Cabinet Committee on Government Administration was charged by Cabinet with the responsibility of considering the report. Writing to Cabinet on 30 October, the committee's chairman, Deputy Prime Minister J.R. Marshall, recommended that the SSCC be authorised to negotiate with the employee unions the adoption of the recommendations and that it consult with the Law Draftsman on the preparation of appropriate legislation for introduction if possible in the current session. The committee also recommended that Recommendation 19 be accepted, with the proviso that the present criterion of "the special conditions applicable to employment in the Police" in respect of determining police salaries and conditions of service be reinstated (SSC, 1968).

Meanwhile, the CSSO met on 30 September to discuss the report (PSA, 1968e). The strongest expression of concern came from new CSSO chairman Ivan Reddish who described the report as "deplorable". The ASRS believed that the commission's constraints on fair relativity would prevent unions from representing a case for an occupational group based on its own merits. The main objection of the NZEI, represented by Delahunty, was the emphasis given to the market in fixing salaries, leaving little scope for the appraisal of particular positions. In an extraordinary contrast to the PSA's subsequent position, especially as enunciated by Long, its president Ray Hannan reported that the PSA had no major concerns with the recommendations but were prepared to go along with any joint policy. The PPTA, meanwhile, went down a different path. Earlier its president had welcomed the recommended criteria, especially recruitment and retention, as an improvement on the present situation (Evening Post, 1968c). At the meeting Boag expressed general satisfaction with Recommendation 19 and disagreed with Delahunty's concerns about the market emphasis, saying that many younger secondary teachers had marketable qualifications and skills. Boag also applauded the commission's attempt to

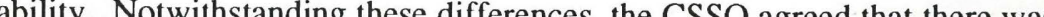
no hurry to discuss the report with the SSC and that they wOuld wait for Govern was no hurry to discuss the report with the SSC and that they would wait for Government action. 
In the negotiations over the incorporation of Recommendation 19 into new legislation the PSA and the NZEI became the driving force behind the CSSO's position, with Long and Delahunty the key personnel. Within one week of the report's transmittal to the Governor-General the industrious Delahunty prepared a seven page analysis of the recommendations relevant to teachers salaries for consideration by the NZEI Dominion Executive. He saw recruitment and retention along with vertical and horizontal relativity as being relevant criteria for teachers' salaries and was particularly concerned with the "market price" philosophy. With regret he noted that the commission had apparently accepted the view that in setting state pay rates:

the necessity is simply to provide a rate which will get sufficient staff of a quality satisfactory to the needs of a particular department ... this ... is not the only one [factor] in wage fixing.... There have been times in the past when has been equally easy and equally difficult to obtain male clerks and male teachers. Does this mean to say that both of these shall receive exactly the male . for that occupation then drop?

Delahunty saw this "market price" philosophy as inadequate for teaching where pay rates should be determined by factors such as required qualifications, responsibilities and intensity of work. He cynically observed that it would be "... little comfort to poorly paid teachers to know that the operation of market affairs was responsible for this and that they would be better off if there was a shortage of teachers." Consequently, he recommended that the criteria include the ability to fix the relative value of teaching (NZEI, 1968/258). This recommendation was adopted by NZEI's Standing Committee the following month (NZEI, 1968d).

Meanwhile, over six weeks after Delahunty's report, Long also prepared a paper which was considered by a PSA subcommittee. His first reaction to Recommendation 19 was that it was "quite unreal and almost certainly likely to be rejected by both employing authorities and Government." Indeed, it would only be welcomed by lawyers, because of the endless arguments over its interpretation. This naive assessment was followed by a more perceptive criticism that Recommendation 19 , by covering every possibility with rules laid down in recommended legislation, left so little scope that it virtually amounted to a negation or denial of the normal rights of conciliation and arbitration. In pay fixing there should be an adequate area in which the parties may advance claims, make concessions and reach settlements. Likewise, an arbitrating tribunal ceases to arbitrate if its hands are tied in most respects. The tribunal simply becomes a rubber stamp for "predetermined lines" laid down by a government in legislation (PSA, 1968f; PSJ, 1968d) Although Long did not refer specifically to it, the importance of scope for negotiation and dispute resolution in pay fixing had also been emphasised by the previous commission (Royal Commission, 1962, pp.352-353).

Another important matter featuring among CSSO concerns raised by Long was subclause (6), which provided for conditions of employment to be fixed according to external comparability (except where special features of employment made this inappropriate). In the SSA conditions of employment were provided for in S.41(6) which did not refer to external comparability. Long saw this recommendation as disadvantageous, although he acknowledged that unions could make considerable use of the exception provision.

On 8 November the SSC took the initiative by writing to the CSSO. They advised that the SSCC had been instructed to open negotiations with the CSSO on the commission's recommendations on the basis of adopting them, subject to minor variations and reservations. On Recommendation 19, the only change the SSC saw as appropriate was inclusion of the existing criterion concerning special conditions for the police. In reporting to the PSA Advisory Council and its subcommittee, Long described Recommendation 19 as "unworkable" and "... we should at this stage insist on this whole aspect being referred to a consultative committee or working party which would study the matter in the forthcoming months." He also reiterated his concern about subclause (6) because the state services career structure rather than external comparability provided the basis for many conditions of employment. Although many conditions, such as annual leave, were ahead of the private sector, these differences were taken into account in pay fixing (PSA, 1968h). The subcommittee (which included Hannan, Barry Tucker, Stan Rodger, Long and Deputy General Secretary Mike Mitchell) resolved that the PSA should oppose the introduction of a bill without prior negotiation and "emphatically oppose" any suggestion that it should be referred to a select committee. While they felt that generally nothing was wrong with the existing criteria, the PSA could indicate a willingness to examine alternative criteria if necessary, bearing in mind the need for flexibility, a relaxation of some of the limitations imposed by internal relativity, and the concept of "work value" (PSA, 1968i). Meanwhile, a note to the CSSO, presumably from Long, argued that if special provision was to be made for the police, it should also be made for teachers, railway employees and others who had no external equivalent (PSA, 1968j). The views of Long and the PSA subcommittee were subsequently incorporated into a CSSO paper, "Wage Fixing Procedures in the State Services" (PSA, 1968k).

At its first meeting with state employing authorities, along with the SSCC and Treasury, on 4 December, the CSSO reported its thoughts that the criteria were too complex and its concern about external comparability prescribing conditions of employment. Delahunty reiterated his concern about the pivotal role of the "market price" and recommended a reference to duties and responsibilities (PSA, 19681). A further SSCC-CSSO meeting was held on 11 December, at which the CSSO agreed to put in writing its position on criteria (PSA, 1968n)

The first real indication of a softening of the CSSO attitude came in a note from Long to the CSSO suggesting that subclauses (1), (2) and (3) of Recommendation 19 might be acceptable if there was reference to margins for skill and responsibility as well as duties (PSA, 1968m). Subsequently, the CSSO wrote to the SSCC suggesting that while Recommendation 19 was still unacceptable, they might not be far apart if the basic principle could be included in legislation with the interpretation and other provisions covered by agreement between the parties (PSA, 1968o). This tactical approach was consistent with the CSSO's view that the criteria should not be too specific, and was followed up by a more detailed "without prejudice" proposal to the SSCC on 24 January 1969 (PSA, 1969a) which was:

(1) Legislation should confined to the intent of subclauses (1)-(3), with the additional reference to "responsibility" in subclause (3)(c).

(2) As subclauses (4) and (5) elaborated on and interpreted the earlier provisions, they should be dealt with in an agreement between the two parties as was the case, in apparently similar circumstances according to the CSSO, in Britain. This agreement should be based on the following points:

(a) "fair comparison" was not the sole determinant;

(b) aspects set out in legislation and in subclauses (4)-(5) would in some cases have to be supplemented by other aspects:

(c) the provisions were to be interpreted as broad guidelines in negotiations, not in a rigid and inflexible manner; and

(d) the need for genuine desire to reach a settlement.

In response, the SSCC rejected the CSSO's proposal for subclauses (4) and (5) and disputed its interpretation of the British situation. Commenting on the components of the CSSO's recommended agreement, the SSCC pointed out that three were either already covered in subclauses (1) and (2) or were unnecessary and superfluous. The fourth, (c), 
was rejected because the SSCC did not consider Recommendation 19, in particular subclause (4) which contained the weighting procedures, to be rigid or inflexible. It was also concerned that if subclauses (4) and (5) were excluded from legislation then, even if contained in an agreement, they could not bind a tribunal. The SSCC did, however, recommend two additions. They suggested that the words "and will take account of special responsibilitios or conditions applying to employment in the occupational class" should be added to subclause (1)(a) while in (1)(b) "Commission" should be replaced by "Employing authority" (PSA, 1969b). Partly a concession to the CSSO, this was also consistent with the earlier decision on references to special circumstances affecting police, and strengthened the needs of particular occupational groups by placing the onus on employing authorities for enforcement.

A turning point in the CSSO approach to the pay fixing criteria came with a paper to the PSA's sub-committee by Mitchell (PSA, 1969c). Reporting on the SSCC's response to the CSSO's proposal and noting the rejection of the recommended separation of subclauses (4) and (5) from legislation, he commented that "Looking at the criteria themselves, one does come to the conclusion after reading them a number of times, that they do not necessarily support the fears one might have on an initial reading." Essentially they contained all the elements of the existing criteria (external and internal relativity and recruitment and retention) with the exception of margins for skill and responsibility. The margins issue was covered in a "somewhat different" form from the SSA in the form of references to vertical relativity (as argued by the commission) but only in relation to the adequacy of margins between benchmark positions and other positions. Furthermore, Mitchell adopted a more sympathetic attitude to subclause (5) arguing that its paragraphs (b), (c), (d), (f) and (g) all conceded points which the PSA had from time to time argued in relation to particular occupation groups.

Mitchell supported accepting the SSCC's recommended addition to subclause (1)(a) because it would mean, in his assessment, that almost any aspect could be revised and argued in relation to an occupational class on the grounds that it related to the specia concluded that because the SSCC's reply did not refer to subclause (6) this may have been conceded to the CSSO.

Mitchell's report, which was at variance with Long's more strident criticisms, led to a change in approach by both the PSA and CSSO. The latter wrote to the SSCC proposing that the words "and the need to maintain adequate margins for skill and responsibility" be added to subclause (3)(b), and that subclauses (5)(c) (which largely excluded the selfemployed from external comparability), and (6) be deleted (PSA, 1969e). The SSCC replied rejecting this proposal, considering that there was already sufficient provision, taking Recommendation 19 as a whole, for a pay fixing authority to take into account margins for skill and responsibility and defending subclause (6) because it would prevent the state from becoming a leader in setting conditions of employment (PSA, 1969f). A subsequent meeting on 22 May between the parties also failed to resolve the stand-of (PSA, 1969h).

The critical breakthrough came when the CSSO met the Cabinet Committee on 17 June. In discussion of the margins issue the committee indicated a favourable attitude contrary to the SSCC, to inclusion of margins for skill and responsibility within the criteria. This was left to the SSCC and CSSO to further discuss (PSA, 1969i). Subsequently, Long reported to PSA Executive Officers that the SSCC had suggested an appropriate wording which he recommended they accept (PSA, 1969k). This culminated in a final agreement between the parties which was subsequently sanctioned by Cabine (PSA, 1969n). The essence of the agreement with regard to criteria was:

(1) Inclusion of the previously agreed wording on special responsibilities or conditions in subclause (1)(a).
(2) Inclusion of the words "and having regard to any differences in skill and responsibility between the bench-mark positions in that occupational class and in other occupations" to the end of subclause (3)(c) concerning horizontal relativity. This was similar, but not identical, to the wording in subclause (3)(b) concerning vertical relativity and was important to the NZEI who had stro inclusion within the CSSO, regarding it as a major gain (NZEI, 1969/753).

(3) The linkage of conditions of employment to external comparability was slightly minimised by replacing the words "according to" with "having regard to" in subclause (6).

(4) The CSSO reserved its position on Recommendations 20 and 21.

This agreement must be seen in a wider context as part of a package. Firstly, the CSSO accepted the commission's recommendations on the use of Department of Labour half-yearly surveys instead of the ruling rate survey and on setting up a pay research un. Secondly, the parties agreed that the CSSO wOuld accept a leter from the Governe Cknowledging that the Government 1960 would still bind the Crown. This was confirmed by Marshall on 25 September (PSA, 1969p). Finally Cabinet, at a meeting on 1 September, agreed to the CSSO's demand that the February 1969 ruling rates survey percentage movement would be applied to tradesmen and that the recommendations of the 1970 Higher Salaries Advisory Committee would be applied (SSC, 1969b). In fact, the wording on the criteria had been resolved in August with fint agreement held over until these latter two matters were resolved in September.

The commission's recommendations, as amended by the SSCC-CSSO agreement, were quickly incorporated into the State Services Remuneration and Conditions of Employment Bill introduced to Parliament on 26 September. During the first reading debate, Marshall complimented the SSCC and CSSO (particularly Rodda and Reddish) for their detailed negotiations. The Opposition also expressed its support, although Stanley Whitehead (MP for Nelson) wanted a greater ability to survey overseas salaries (NZPD, 1969b, pp.3082-86). Such was the consensus that the Bill was not referred to a select committee and instead quickly went through the second and third reedings com second reading debate Minister of Labour Tom Shand, commenting on the lengthy SSCC-CSSO negotiations, said:

Clause by clause they went through the recommendations of the Royal Commission and these have been argued back and forth - and when I wrote these words I was tempted to say 'and fifth and sixth, and sometimes twelfth' - but eventually agreement was reached .... and there has been some considerable concession on both sides (NZPD, 1969c, p.3364)

In a fair summary he added, "From the positions initially adopted there has been a greater concession on the part of the employee representatives than on the part of the Government representatives..." (ibid.).

\section{Conclusion}

Since the Public Service Consultative Committee Report in 1946, when the fai relativity principle was first introduced into state pay fixing, its development has been evolutionary, leading to the SSRCE 1969 . In fact, this evolutionary progress continued for nearly 20 years, until the abrupt introduction of the State Sector Bill in December 1987. Emerging as a pay fixing principle from the Consultative Committee's Report, fair relativity was given legislative sanction, still as a principle, in the SSA. This legislation, largely incorporating the recommendations of the preceding Royal 
Commission, not only placed pay fixing principles into legislative form, but also made a distinction within the fair relativity principle between external and internal relativity. Following dissatisfaction with the application of these principles, along with concurrent discontent with the ruling rates survey, the 1969 Act incorporated almost entirely the recommendations of the 1968 Royal Commission; principles became criteria, and new (hen weighted with priority given to the most appropriate approximation to the "market price".

Although fair relativity as part of the pay fixing regime developed in an evolutionary manner, it was on the basis of conflict rather than consensus. The 1945/46 Consultative Committee was formed after a period of considerable disharmony, including industrial action. The 1968 Commission was established in the aftermath of conflict including disputed tribunal rulings and industrial action; such was the hostility and suspicion that it was boycotted by the CSSO. The subsequent negotiations leading to the SSRCE Act, while eventully achieving resolution, involved significant concessions, more so on the while eventully achieving resolution, involved 1962 Royal Comsission and the SSA. union side. The possible exception was the 1962 Royal Commission and the SSA. However, in the former pay fixing was only one part of a much wider warrant while the latter incorporated, at the level of generality, principles that were to a large extent already in operation.

Finally, the performance of the state sector unions was, on important occasions, unimpressive and generally reactive rather than proactive. The PSA was successful in formulating the initial fair relativity principle as part of the Consultative Committee and this principle continued for over 20 years as a broad-brush approach to pay fixing. However, the CSSO leadership, although understandably suspicious of the Government's motives, made a fatal error in absenting itself from the criteria debate within the 1968 Commission. By not participating they relegated this debate to one essentially between employers (and employing authorities) and administrators, rather than between employers and unions. By the time the negotiations over legislation occurred the CSSO had already conceded a fundamental position - that pay fixing criteria should be broadly based rather than specific and weighted. While they had subsequent negotiating successes this was than specific and weighted. While they had subsequent negotiating successes this was
within the framework of the latter rather than the former. Although some unions did participate in the Royal Commission this was on the basis of individual concerns and lacked a central coordinated perspective. It is a moot point whether the Commission would have produced different pay fixing recommendations had the CSSO participated, but the loss of this opportunity to influence the Commission and to reserve its position for subsequent negotiations was reactive and unwise.

\section{References}

Bay of Plenty Times (1968) Syndicated Neale McMillan article on NZEI and PPTA decision to participate on Royal Commission, 16 March.

Boston, Jonathan (1984) Incomes policy in New Zealand Victoria University Press, Wellington.

Christchurch Press (1968) CSSO decision not to participate in Royal Commission (editorial) 4 March

Department of Labour Pay Fixing in the State Services.

Evening Post (1968a) CSSO statement on non-participation in Royal Commission, 28 February.
Evening Post (1968b) Sir Thaddeus McCarthy's comment on CSSO non-participation decision, 13 March.

Evening Post (1968c) PPTA reaction to 1968 Royal Commission Report, 10 September Hunn, Jack (1982) Not only affairs of state Dunmore Press Ltd., Palmerston North.

Interdepartmental Committee (1966) Report on General Wage Orders and other wage increase procedures in New Zealand (Treasury, Labour, Industries and Commerce and Statistics Departments) Government Printer, Wellington.

New Zealand Educational Institute (1968a) Executive or Standing Committee Decisions, Internal file, Item 10, 17 January.

New Zealand Educational Institute (1968b) Executive or Standing Committee Decisions, Internal file, Item 99, 26 February.

New Zealand Educational Institute (1968c) Executive or Standing Committee Decisions, Internal file, Item 497, 30 September.

New Zealand Educational Institute (1968d) Executive or Standing Committee Decisions, Internal file, Item 537, 29 October

New Zealand Educational Institute (1967/293) Internal file, Appendix, 14 December Royal Commission Terms of Reference.

New Zealand Educational Institute (1968/35) Internal file, Appendix, 1 February, participation in Royal Commission debate.

New Zealand Educational Institute (1968/43) Internal file, Appendix, 20 February, CSSO boycott position.

New Zealand Educational Institute (1968/52) Internal file, Appendix, 29 February, NZEI policy on pay fixing machinery.

New Zealand Educational Institute (1968/258) Internal file, Appendix, 3 September, Royal Commission Report and recommendations.

New Zealand Educational Institute (1969/253) Internal file, Appendix, 15 August, SSCCCSSO agreement.

New Zealand Parliamentary Debates (NZPD) (1969a) v. 364.

New Zealand Parliamentary Debates (NZPD) (1969b) v. 363.

New Zealand Parliamentary Debates (NZPD) (1969c) v. 364.

Otago Daily Times (1968) CSSO decision not to participate in Royal Commission, 29 February. 
Public Service Association (1968a) CSSO Central Committee Minutes, 14 February. Internal file PSA G/5/2.

Public Service Association (1968b) PSA General Secretary to Civil Service Legal Secretary, 29 April. Internal file PSA G/5/2.

Public Service Association (1968c) PSA General Secretary to Aircraft Surveyors Group, 25 March. Internal file PSA G/5/2.

Public Service Association (1968d) PSA General Secretary to Mr G Ross, Masterton, 20 March. Internal file PSA G/5/2.

Public Service Association (1968e) CSSO Central Committee Subcommittee Minutes, 30 September. Internal file PSA G/5/2.

Public Service Association (1968f) D Long, "Notes on Royal Commission", to PSA Subcommittee, 21 October. Internal file PSA G/5/2.

Public Service Association (1968g) SSC to CSSO, 8 November. Internal file PSA $\mathrm{G} / 5 / 2$.

Public Service Association (1968h) D Long, Report to PSA Advisory Council and Executive Royal Commission Subcommittee, 19 November. Internal file PSA G/5/2.

Public Service Association (1968i) Notes on PSA Royal Commission Subcommittee, 20 November. Internal file PSA G/5/2.

Public Service Association (1968j) CSSO Central Committee Note for Members, Organisation, 22 November. Internal file PSA G/5/2.

Public Service Association (1968k) CSSO Central Committee Paper, Wage fixing procedures in the state services, 27 November. Internal file PSA G/5/2.

Public Service Association (19681) Report on 4 December meeting betwen CSSO and Employing Authorities, 10 December. Internal file PSA G/5/2.

Public Service Association (1968m) Secretary (Long) to CSSO, 11 December. Internal file PSA G/5/2.

Public Service Association (1968n) CSSO Central Committee Circular, 13 December. Internal file PSA G/5/2

Public Service Association (19680) CSSO to SSCC, 13 December. Internal file PSA $\mathrm{G} / 5 / 2$.

Public Service Association (1969a) CSSO to SSCC, 24 January. Internal file PSA $\mathrm{G} / 5 / 2$.

Public Service Association (1969b) SSCC to CSSO, 18 March. Internal file PSA G/5/2.

Public Service Association (1969c) M Mitchell, Note to PSA Subcommittee, 8 April. Internal file PSA G/5/2.
Public Service Association (1969d) M Mitchell, Wage fixing criteria paper to PSA Subcommittee, 8 April. Internal file PSA G/5/2.

Public Service Association (1969e) CSSO to SSCC, 18 April. Internal file PSA G/5/2. Public Service Association (1969f) SSCC to CSSO, 24 April. Internal file PSA G/5/2. Public Service Association (1969g) Report of Subcommittee to PSA, 6 May. Internal
file PSA G/5/2.

Public Service Association (1969h) CSSO Central Committee Circular, 10 June. Internal file PSA G/5/2.

Public Service Association (1969i) CSSO Central Committee Circular, 19 June. Interna file PSA G/5/2.

Public Service Association (1969j) PSA Report Wage fixing procedures: action taken on Royal Commission Recommendations, no date (late June). Internal file PSA G/5/2.

Public Service Association (1969k) General Secretary note to PSA executive officers, 9 July. Internal file PSA G/5/2.

Public Service Association (19691) PSA Report on progress of negotiations to Executive Council, 28 July. Internal file PSA G/5/2.

Public Service Association (1969m) CSSO to Deputy Prime Minister, 12 August. Internal file PSA G/5/2.

Public Service Association (1969n) CSSO Central Committee Circular, 25 September Internal file PSA G/5/2.

Public Service Association (1969o) Negotiated agreement between SSCC and CSSO: Royal Commission on Salary and Wage Fixing Procedures, no date (September). Internal file PSA G/5/2. Public Service Association (1969p) CSSO Central Committee Circular, 30 September.
Internal file PSA G/5/2.

Public Service Consultative Committee on Salaries (1946) Report (1945-46) Government Printer, Wellington.

Public Service Journal (1967a) The tradesmen's 6d, April.

Public Service Journal (1967b) Arbitration?, April.

Public Service Journal (1967c) The tradesmen's 6d, May-June.

Public Service Journal (1967d) The tradesmen's 6d, July.

Public Service Journal (1967e) The threat, November. 
Public Service Journal (1968a) Continuing threat, February.

Public Service Journal (1968b) The Royal Commission, March.

Public Service Journal (1968c) SSC at Royal Commission, May.

Public Service Journal (1968d) The machine of a million immovable parts, November. Public Service Journal (1969) Winds of change, October.

Public Service Journal (1986) All-out assault on state pay, 22 October-18 November.

Randle, D (1985) Industrial relations in the public sector Industrial Relations Centre, Victoria University, Wellington.

Robertson, J F (1974) Legislation and industrial relations in the public sector. In Howells, J, Woods, N and Young, F J L (eds) Labour and industrial relations in New Zealand Sir Isaac Pitman (Australia), Pty. Ltd.

Roth, Bert (1987) Remedy for present evils NZPSA, Wellington.

Royal Commission of Inquiry (1962) The state services in New Zealand Government Printer, Wellington.

Royal Commission of Inquiry (1968) Salary and wage fixing procedures in the New Zealand State Services Government Printer, Wellington.

Royal Commission of Inquiry (1968) List of relevant submissions

$\begin{array}{ll}\text { No. } & \text { Organisation } \\ 4 & \text { Law Draftsman } \\ 5-6 & \text { Post Office, Papers No. 1 and 2 } \\ 15 & \text { SSC, Background Paper No. 2 } \\ 17 & \text { Department of Education } \\ 32 & \text { SSC, Wage Fixing Criteria } \\ 39 & \text { Post Office, Criteria } \\ 42 & \text { Treasury, Criteria for Wage and Salary Fixing in } \\ & \text { the State Services } \\ 48 & \text { NZ Veterinary Association } \\ 52 & \text { Medical Association of New Zealand } \\ 56 & \text { NZ Government Railways Department } \\ 57 & \text { Department of Education } \\ 61 & \text { Department of Health } \\ 62 & \text { NZ Institute of Engineers } \\ 63 & \text { NZEI } \\ 75 & \text { NZ Commissioner of Police } \\ 77 & \text { NZ Master Builders' Federation } \\ 79 & \text { Medical Association of New Zealand } \\ 82 & \text { NZ Police Association and NZ Police Officers' } \\ & \text { Guild } \\ 83 & \text { Hospital Boards Association of New Zcaland } \\ 84 & \text { Department of Labour, Ruling rates survey }\end{array}$

No number

NZ Association of Scientists

SSC, Ruling rates survey

Director, Fruit Division, Department of Scientific and Industrial Research

NZ Employers' Federation

PPTA

Department of Scientific and Industrial Research NZ Hospital Officers Association

ATTI

Government Statistician, Fair relativity as a criterion

University Institutions of New Zealand

NZ Government Employees' Association

Associated Chambers of Commerce

Civil Service Institute

NZ Hospital Physicists Association

TCA

Department of Education

NZ Psychological Society

Department of Labour, Ruling rates survey and use of data from half-yearly surveys, as a measure of general wage adjustment

SSC final submission

State Services Commission (1965-70) Annual reports Government Printer, Wellington.

State Services Commission (1966) Paper on ruling rates survey and wage fixation 3 November, Internal file SSC 12/010.

State Services Commission (1967) SSCC Subcommittee report on the ruling rates survey system 28 March, Internal file SSC 12/010.

State Services Commission (1968) Memorandum from J.R. Marshall, Chairman, Cabinet Committee on Government Administration, to Cabinet, 30 October. Internal File SSC $3 / 6 / 32$.

State Services Commission (1969a) CSSO to Cabinet Committee on Government Administration, 29 August. Internal file SSC 3/6/32.

State Services Commission (1969b) Cabinet Secretary to Cabinet Committee on Government Administration, 8 September. Internal file SSC 3/6/32.

State Services Commission (1969c) CSSO to SSCC, 11 September. Internal file SSC $3 / 6 / 32$.

Truth (1968) Attack on CSSO and PSA by GEA for non-participation decision, 5 March.

Walsh, Pat (1988) The Buff Paper revisted: the development of state sector industrial relations in New Zealand Working paper 3/88, Industrial Relations Centre, Victoria University, Wellington. 


\section{LOW PAY AND THE MINIMUM WAGE}

Peter Brosnan and Frank Wilkinson

\section{Can we afford the burden of low pay?}

Essential reading for trade unionists, employers, government officials and everyone concerned with equity and efficiency in the economy.

A forcefully argued case for a substantial increase in the Minimum Wage. Shows how low paid workers subsidise inefficient employers.

Costs carefully, sector by sector, the impact of a realistic Minimum.

Contents include:

Who are the low paid in New Zealand?

The Minimum Wage

New Zealand's obligations under international law

Government policy and low pay

Low pay and household poverty

Low pay and the pay equity debate

A case study: The economics of contract cleaning

Low pay and the economy

What would a realistic Minimum Wage cost?

PUBLISHED BY New Zealand Institute of Industrial Relations Research Industrial Relations Research Monograph No. 2.

\section{Introductory offer}

Price normally $\$ 24.95$ - Special introductory offer $\$ 22.45$

Order from: $\quad$ Publications Manager

Box 28093

Wellington

The introductory price of $\$ 22.45$ each includes GST and postage in New Zealand. Make cheques payable to: "New Zealand Institute of Industrial Relations Research" 